Esta publicación cientifica en formato digital es continuidad de la revista impresa ISSN-Versión Impresa 0798-1406 / ISSN-Versión on line 2542-3185Depósito legal pp
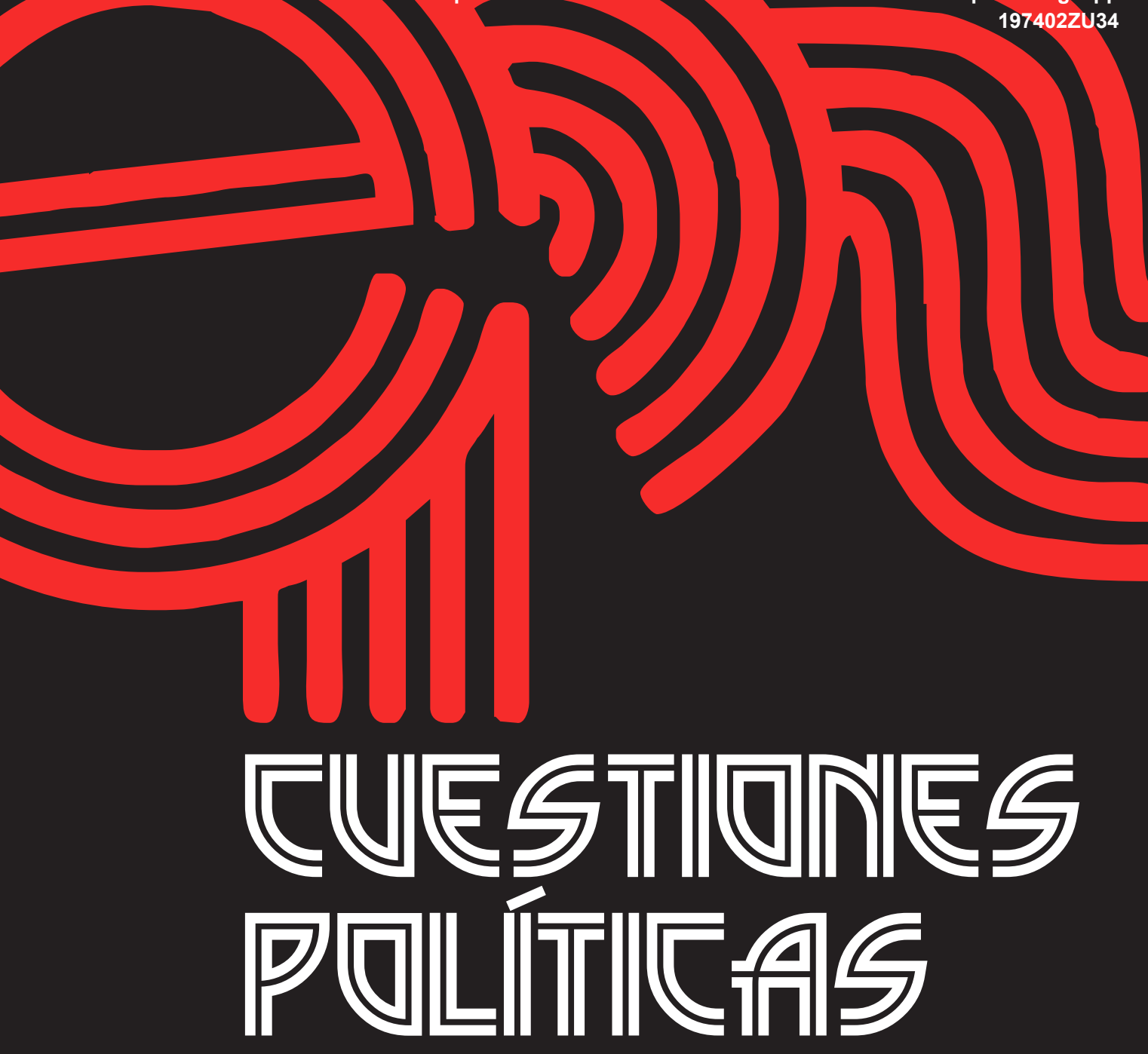

Instituto de Estudios Políticos y Derecho Público "Dr. Humberto J. La Roche" de la Facultad de Ciencias Jurídicas y Políticas de la Universidad del Zulia Maracaibo, Venezuela
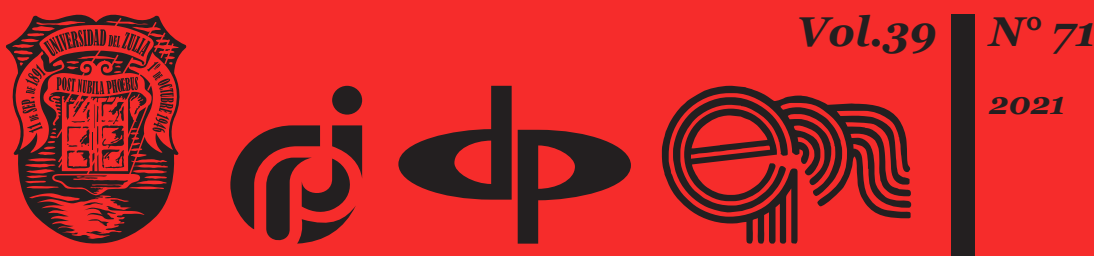


\title{
Peculiarities of Realization of the International Mechanism for the Protection of the Rights of Victims of Armed Conflict in the East of Ukraine
}

\author{
DOI: https://doi.org/10.46398/cuestpol.3971.17
}

\author{
Alexander G. Kolb * \\ Malvina Hrushko ** \\ Hanna Teteriatnyk *** \\ Olha Chepik-Trehubenko **** \\ Olha Kotliar *****
}

\section{Abstract}

The article analyzes the content of international legal acts related to the protection of the rights of victims of military conflicts. At the same time, its results identify the characteristics of its implementation in Ukraine. It has been established that some of these legal sources have not been ratified by Ukraine or otherwise Ukraine has not given them a binding legal effect. Using a documentary-based methodology close to legal and political hermeneutics, this article develops scientifically sound and relevant proposals aimed at improving the legal mechanism to protect the legitimate interests and rights of the victims of the military conflict in Eastern Ukraine. It is concluded that the current legal problems not only negatively affect the state of law enforcement activity in Ukraine, which is directly related to the content of this process, but also does not allow adequate influence on the determinants that give rise to, and cause military and territorial conflicts in Ukraine, a situation that can be extrapolated to other societies near or far.

Keyword: victim of armed conflicts; legal norm; hybrid war; ratification of international treaties; international agreement.

Doctor in Law, professor of departament of Political Science and Public Administration, Lesya Ukrainka Volyn National University. ORCID ID: https://orcid.org/oooo-0o03-1792-4739

* Docent of department of International and European Law of the National University "Odessa Law Academy”, faculty of international legal relations, candidate of Law, docent. ORCID ID: https://orcid. org/oooo-0002-5856-8147

*** Head of department of Criminal Procedure of Odessa State University of Internal Afairs, candidate of Law, docent. ORCID ID: https://orcid.org/oooo-0002-8321-7912

**** Docent of department of General Law, Dnipropetrovsk State University of Internal Affairs, faculty of law, candidate of Law. ORCID ID: https://orcid.org/oooo-0001-5499-5793

***** Docent of department of International Law, State Higher Educational Institution "Uzhhorod National University", candidate of Law. ORCID ID: https://orcid.org/oooo-00o2-3485-4157 


\section{Peculiaridades de la aplicación del mecanismo internacional de protección de los derechos de las víctimas de conflictos armados en Ucrania oriental}

\section{Resumen}

El artículo analiza el contenido de los actos jurídicos internacionales relacionados con la protección de los derechos de las víctimas de conflictos militares. Al mismo tiempo, sus resultados identifican las características de su implementación en Ucrania. En particular, se ha establecido que algunas de estas fuentes legales no han sido ratificadas por Ucrania o, de lo contrario, Ucrania no les ha dado un efecto legal vinculante. Mediante una metodología de base documental próxima a la hermenéutica jurídica y política este artículo desarrolla propuestas científicamente sólidas y relevantes destinadas a mejorar el mecanismo legal para proteger los intereses y derechos legítimos de las víctimas del conflicto militar en el Este de Ucrania. Se concluye que los problemas legales actuales no solo afectan negativamente el estado de actividad de la aplicación de la ley en Ucrania, que está directamente relacionado con el contenido de este proceso, además tampoco permite influir adecuadamente en los determinantes que dan lugar y causan conflictos militares y territoriales en Ucrania, situación que puede extrapolarse a otras sociedades cercanas o lejanas.

Palabras clave: víctima de conflictos armados; norma legal; guerra híbrida; ratificación de tratados internacionales; acuerdo internacional.

\section{Introduction}

According to modern realities in Ukraine, on the way to its future membership in NATO and the EU, as well as the full implementation of relevant state programs regarding ensuring the fundamental rights and freedoms of human and citizen, a serious problem has arisen, namely: terrorist activity and in general a hybrid war of the Russian Federation, which is carried out by military units of this country and separatists (French separatism; Latin separatus - separated from society) (Decree of the President of Ukraine, 2015; Bulko, 2010). in the Donbass (Donetsk and Luhansk regions). As a result, almost 11 thousand terrorist acts (and, in fact, the results of the armed conflict), which have been committed by 1 thousand 375 people, took place only in 2014-2019 on the territory of our state.

Similar trends persisted in subsequent 2020-2021 years. Moreover, the specific gravity of criminal offenses of this nature, which resulted from the military conflict in the East of Ukraine, is almost $11 \%$ of the total number of the socially dangerous acts that encroach on the public safety. 
Alexander G. Kolb, Malvina Hrushko, Hanna Teteriatnyk, Olha Chepik-Trehubenkoy Olha Kotliar
Peculiarities of Realization of the International Mechanism for the Protection of the Rights of
336 Victims of Armed Conflict in the East of Ukraine

Regarding the structure of these criminal offenses, it is dominated by terrorist acts (71.68\%). In general, the specified offenses are also committed by:

1. creation of a terrorist group or terrorist organization, as well as participation in it $-23.65 \%$.

2. terrorist financing $-4.16 \%$.

3. committing other terrorist acts (military actions of a hybrid nature) $-0.51 \%$.

Although the Global Index of Terrorism places Ukraine only 24th out of 138 countries of the world, the level of terrorist attacks on the national security of our state, its state sovereignty, territorial integrity, and other objects of legal protection, referred to the art. 111 of the Criminal Code of Ukraine, according to international experts, is the highest, given the threats that are posed by the hybrid war of the Russian Federation in the Donbass.

This conclusion is based on the following empirical materials:

1. terrorist activity in the East of Ukraine (as a type of hybrid war) has a group character (consolidated, united, and purposeful).

2. military aggression on this territory is carried out with active use of modern types of armor and conducting combat operations on the basis of new developments and technologies.

3. creation of terrorist groups or terrorist organizations, such as the "LPR" and "DPR" (respectively Luhansk and Donetsk People's Republics) is done by military professionals, as well as military formations and security agencies of the Russian Federation.

4. illegal armed groups "LPR" and "DPR" are stable criminal associations that operate in conjunction with military units of the Russian Federation.

5. sources of financing terrorist activity in Ukraine are: funds of the aggressor state; financial income from illegal business in our state (sale of drugs, psychotropic substances, money, etc.); funds that are received from certain political forces, as well as from the secret funds of international terrorist organizations "Al Qaeda", "Al-Islamiya", "Al-Qiyam", etc.;

6. members of terrorist groups and organizations are males, who are $30-45$ years old ( $82 \%$ in the structure of all participants in the hybrid war in Ukraine) (Mokliak, 2020).

Thus, it should be recognized that there is a complex applied problem that needs to be solved at the doctrinal level, given the peculiarities of the 
protection of the rights of victims of the armed conflict in Donbass, in this regard, problems that are related to the inconsistency of domestic law and norms of international law on the specified issues.

\section{Description (statement) of the problem}

For the eighth year in a row, the so-called "hybrid war" (war with a combination of terrorism, cyber warfare, and criminal behavior in order to create internal contradictions and conflicts in a country chosen for aggression by an aggressor state) with the Russian Federation, its victims were more than 14 thousand servicemen and civilians, as well as significant (according to experts) material damage to our country as a whole and to individual citizens.

Thus, feature of military actions in the specified territory of Ukraine is that until now:

1. This military-political conflict is not recognized as war at the level of legislative and executive power of both warring countries, therefore, its content and consequences do not fall under the scope and jurisdiction of a number of key international legal acts, which regulate the specified issue (according to some researchers, it is almost 50 such legal sources, of which only $20 \%$ have been ratified by Ukraine (Khavroniuk, 2005).

2. The legal guarantees and other preferences (from French preference - advantage; Latin preferred - privilege; advantage), which are provided by the norms of international law for victims of military conflicts do not apply to persons who do not fall under the status of refugees, but are considered internally displaced persons (Bulko, 2010; Verkhovna Rada of Ukraine, 1977; Verkhovna Rada of Ukraine, 1951; Verkhovna Rada of Ukraine, 2014).

3. If the term "victim of a crime" is used in the norms of international law, then "victim" is used in the national legislation that is not identical with regard to the protection and legal guarantee of the specified statuses of the person.

In particular, the victim of a crime is understood as a person or a community of people in any form of their integration, who are directly or indirectly harmed by the crime (Golina et al., 2014). It should be noted that this term is not enshrined at the legislative level in Ukraine.

In turn, the following concept of "victim" has been formulated in the part 1 of art. 55 of the Criminal Procedure Code (CPC) of Ukraine, namely, it is a natural person who has suffered moral, physical or property damage as a result of a criminal offense, as well as a legal entity that has suffered property damage by a criminal offense. 
1. Those guilty of committing unlawful military acts in eastern Ukraine are not prosecuted for crimes against peace, security of mankind and international law and order (Section XX of the Criminal Code (CC) of Ukraine), but are prosecuted for committing terrorism or criminal offenses against the foundations of national security, public safety and the individual, which, again, is not identical in terms of international legal mechanisms for the protection of victims (Verkhovna Rada of Ukraine, 1977).

Namely, these circumstances that necessitated the scientific development of this problematic, as well as determined the theoretical and applied significance of this article.

\section{Analysis of the recent research}

The closest to the subject of this scientific article are the doctoral theses of Yu. V. Danylchenko and O.O. Stepanchenko, as well as V.V. Mokliak thesis for the degree of candidate of law (Danylchenko, 2018; Stepanchenko, 2018; Mokliak, 2020).

At the same time, in the context of the peculiarities of the military events taking place in the East of Ukraine, and existing problems in this regard, the chosen research topic is aimed not so much at expanding the boundaries of theoretical knowledge about the phenomena of terrorism, but at developing effective measures, aimed at improving the legal mechanism for the protection of victims from the hybrid warfare, taking into account the potential opportunities of norms of international law on this issue.

This, in fact, is the purpose of this scientific article, and its main task is to clarify the gaps, conflicts and contradictions that exist between the content of relevant international legal acts and the legislation of Ukraine, which regulate public relations that are related to the protection of the rights of victims from the military conflicts.

\section{Materials and methods}

This scientific article uses both general scientific and special scientific methods. The methodological basis of this work is a dialectical method of scientific cognition of social legal phenomena and processes in their contradictions, development, and changes, which made it possible to objectively assess the state and effectiveness of the realization of the international mechanism for the protection of the rights of victims of the military conflict in the East of Ukraine. 
In turn, the priority in the course of this research was the comparative legal method, by means of which it was possible to establish the existing discrepancies (contradictions, conflicts and gaps) between the norms of international law and the legislation of Ukraine on the specified problematic.

The application of the system-legal method allowed to consider the investigated elements of the subject of this scientific article as an interconnected and mutually conditioned set of normative-legal acts of international and domestic character, as well as to formulate in this direction systemic measures aimed at improving the legal mechanism for the protection of the rights of victims of the military conflict in the East of Ukraine.

The formal-dogmatic method has created appropriate conditions for substantiation of the conclusions that are formulated in this work both on divisions (there are three of them in it), and as a whole on the given scientific work.

Important in the course of this research was the role of methods of analysis and study of documents, by means of which the content of the international legal acts and norms of the current legislation of Ukraine on issues of protection of victims of hybrid war in Donbass is found out, as well as the essence and direction of scientific developments on the specific problematic.

Statistical methods gave the opportunity to determine quantitative and qualitative indicators, characterize the state and trends of protection of the rights of victims of the military conflict in the East of Ukraine.

In one way or another, in the context of solving the local tasks of this scientific article, it uses the possibilities of other scientific methods (social naturalism - in justifying the priority of natural human rights, namely - the principle of the rule of law; synthesis - if the need to harmonize the norms of international law and legislation of Ukraine; induction and ascent from the abstract to the concrete - to clarify the content of the key concepts of this scientific article ("hybrid war"; "refugee"; "temporarily displaced person"; "victim of a criminal offense", etc.) and their relationship between them .

This research methodology allowed to fully achieve the goal and implement the defined in this work main task.

The results of the conducted research of the content of international legal acts and current legislation of Ukraine, which relate to the content of protection of the rights of victims of military conflicts, have showed that the effectiveness of their realization in practice is influenced by several significant circumstances that constitute certain elements of the content of the subject of this scientific article.

Regulatory and legal incompatibilities between the above-specified legal sources. First, it concerns those international legal acts that have been ratified or, in one or another way that is specified in the law, have become mandatory for implementation on the territory of Ukraine. 
Alexander G. Kolb, Malvina Hrushko, Hanna Teteriatnyk, Olha Chepik-Trehubenko y Olha Kotliar Peculiarities of Realization of the International Mechanism for the Protection of the Rights of Victims of Armed Conflict in the East of Ukraine

As it is stipulated by part 1 of article 9 of the Constitution of Ukraine, the current international agreements that are approved by the Verkhovna Rada of Ukraine, are part of the national legislation of Ukraine.

At the same time, in accordance with the requirements of the Law of Ukraine "On international agreements", international legal acts come into force in Ukraine in different ways, namely:

1. through the procedure of ratification, approval, acceptance, or accession (according to the articles 9, 12, 13 of this Law).

2. when an international treaty is signed, ratified, approved, accepted, or acceded to, declarations and cautions may be made to its provisions in accordance with norms of international law.

As a result, it should be stated that today in Ukraine more than 40 international legal acts, which have a direct relation to the investigated problematic in this scientific article, have not acquired legal force.

These include such important norms of international law as:

- European Convention on the compensation for victims of violent crimes of November 24, 1983 (Verkhovna Rada of Ukraine, 1983);

- $\quad$ Rome Statute of the International Criminal Court of July 17, 1998 (Verkhovna Rada of Ukraine, 1998).

- Declaration of basic principles of justice for victims of crime and abuse of power of November 29, 1985, and others (Verkhovna Rada of Ukraine, 2011; Khavroniuk, 2005).

This approach has an extremely negative impact on activity of Ukraine to protect victims from the hybrid warfare in the East, whereas there is still no proper in our country legal mechanism on these issues, given the requirements of international law.

Moreover, there is a discrepancy between the content of the laws of Ukraine and international legal acts governing this area of public relations in many cases.

Thus, the term "refugee" is used in the norms of international law in relation to persons, who are affected by military conflicts of various character, the term "temporarily displaced person" is used in the current legislation of Ukraine, which do not match in their status.

In particular, a refugee is a person who has become a refugee as a result of events prior to January 1, 1951, and due to well-founded fears of being persecuted on racial grounds, religion, nationality, membership of a particular social group or political opinion, who has been outside the country, his national identity and has been unable to enjoy the protection 
of that country or has not wished to enjoy such protection due to such fears or has not been able or has not wanted to return to it due to such fears, not having a certain citizenship and being outside the country of their former place of residence as a result of such events.

In turn, albeit the provisions of the Convention are reproduced in full, but a legally significant remark (French remarque - note) about that, a citizen of Ukraine cannot be a refugee is also made in the Law of Ukraine "On refugees and people, who need the additional temporary protection"(Bulko, 2010).

At first glance, everything seems logical, because how can refugee be a person, who lives in the country of which he is a citizen?

At the same time, the citizens of Ukraine, foreigners and stateless persons who are on the territory of Ukraine on legal grounds and have the right to permanent residence in Ukraine, who were forced to leave their place of residence as a result or in order to avoid the negative consequences of armed conflict, temporary occupation, generalized violence, human rights violations and emergencies of natural or technical nature (part 1 of the article 1) are considered to be such people in the Law of Ukraine "On ensuring the rights and freedoms of internally displaced persons".

In this regard, a logical question arises, what status is more extensive in the context of a hybrid war and, in fact, the open aggression of the Russian Federation in the East of Ukraine?

As it appears, it is necessary to clarify the meaning of other terms that are used in connection with this in the norms of international law in order to give an answer in this regard.

First of all, this applies to the term "aggression", which is widely used at the normative and legal, doctrinal, applied and other levels in Ukraine.

This term without official interpretation is used in the art. 437 of the Criminal Code "Planning, preparation, resolution and conduction of aggressive war" in the legislation of Ukraine.

Moreover, nobody has been prosecuted for the commission of this criminal offense since the entry into force of this Code in 2001, including the period 2014-2021.

As practice shows, the main obstacle for the justice is the lack of such an important feature in the objective side of the specified criminal offense, as way, - the application of armed force by the aggressor state directly against the state of Ukraine, whereas the latter has not declared yet a state of war with Russia at the political and legal level, which is a necessary condition of recognizing its actions as aggression, as this follows from the content of the relevant norms of international law. 
Thus, the aggression means the use of armed force by a state (group of states) against the sovereignty, territorial integrity, political independence of another state or people (nation), is incompatible with the UN Charter in the UN Convention of March 23, 1934.

However, in this sense, it should be noted that in the scientific literature there are other approaches, according to which aggressive war can be called the events of military conflict, which occur without declaring war on the aggressor state (Maliar, 2016).

This position does not seem to be acceptable, given that Ukraine still does not comply with the requirements of the UN General Assembly Convention of December 14, 1974, in which the concept of "aggression" is divided into two types that are not used in the legal practice of our country, namely:

1. aggression that leads to international responsibility.

2. aggression, which is a crime against international peace (UN General Assembly, 1974).

Apart from this, in this sense is the resolution of the Verkhovna Rada of Ukraine dated 21.04.2015 № 337-VIII "On the statement of the Verkhovna Rada of Ukraine "On responsing the armed aggression of the Russian Federation and overcoming its consequences", which has a more political meaning, as it also did not enshrine the fundamental principles that are set out in the above-mentioned UN Convention (Verkhovna Rada of Ukraine, 2015).

Indicative and at the same time instructive in this context is the social and legal paradox that has developed in connection with the events, which occur in the East of Ukraine, namely: if there is a hybrid war in the specified territory, why are its participants from both parties not called prisoners of war in cases of their detention and why are they subject to international legal acts that govern this issue (Verkhovna Rada of Ukraine, 1949).

At the same time, the separatists of the quasi-republics "LPR" and "DPR", having no domestic legislation, use the Criminal Code of Ukraine and prosecute servicemen of the Armed Forces and other formations of Ukraine for committing general criminal offenses (terrorist act; premeditated murder; illegal handling of weapons; etc.), thus giving these persons the status of a convict, not a prisoner of war.

Domestic courts follow the same path, as they do not have legal grounds to recognize participants in a military conflict for the reasons that are discussed above.

Therefore, until Ukraine ratifies the Rome Statute of the International Criminal Court and applies its norms to Russian servicemen, mercenaries and separatists who are waging a hybrid war in the East of our state, we will not be able to provide adequate legal protection to the victims of this military conflict and, in fact, but not from a legal point of view to Russian aggression. 
Important in this regard is another conclusion that the fundamental principle of the rule of law is enshrined in international law, as, in fact, in the Constitution of Ukraine (article 8), which is a necessary prerequisite for the alignment (harmonization, convergence, etc.) of domestic legislation and international legal acts, which regulate the issue of protection of the rights of victims (no matter how they are defined at the regulatory level (refugees; internally displaced persons; victims of military conflicts; etc.)) (Golovatyi, 2006).

The second key problem, which has an extremely negative impact on the effectiveness of the realization of the international mechanism for the protection of the rights of victims of the military conflict in the East of Ukraine, is the low level of fulfillment of commitments of our country.

As a result, everyyear Ukraine, on the one hand, becomes a subject of judicial proceedings in the European Court of Human Rights (ECHR), on the other hand, is forced to pay significant funds for victims of inaction and wrongful acts of officials of relevant government agencies, institutions, enterprises and organizations, as it is provided by the Law of Ukraine of 23.06.2006 "On the implementation of decisions and application of the case law of the European Court of Human Rights" (Verkhovna Rada of Ukraine, 2006).

In particular, as it has been established in the course of special scientific research, the ECHR has so far adopted almost 200 decisions, in which it stated the Ukraine's violation of articles 2 and 3 of the Convention for the Protection of Human Rights and fundamental freedoms of November 4, 1950, regarding its citizens.

At the same time, according to the decisions of the European Court of Human Rights, our state annually pays from 25 to 30 million hryvnias (Podilchak, 2015).

If to evaluate the specified legal facts in view of the structure of offenses that have been committed by Ukraine, it has the following view:

a) this is a procedural violation (21\% of the total number that are related to ineffective investigation).

b) 15 violations, which were consequences of torture of the person (9\%).

c) 59 violations concern cases of inhuman and degrading treatment (34\%).

d) 62 violations (non-response or ineffective investigation of complaints of citizens) (36\%) (Babin, 2015).

According to social and political practice, the main reason of the low level of executive discipline in our country is the mentality (from Latin mentalis - way of thinking), that formed in Ukrainian society, namely: 
from the President of Ukraine, people's deputies and other government officials, including judges who take an oath to serve the law (adhere to the international principle of the rule of law, as well as to ordinary citizens in certain legally significant situations promises, voluntary commitments are made, etc., but already at achievement of the desirable purpose (election as the President of Ukraine, etc.) everything at once "is forgotten" for some reason - this is immoral, and in the West this is unacceptable behavior that undermines the reputation (French reputation, Latin reputation - thinking; creating a general opinion about the human virtues of a certain person) of our state as a whole in the international arena (Golovatyi, 2006; Bulko, 2010).

Indicative in this sense is the behavior of representatives of Ukraine in relations with the International Monetary Fund (IMF), when our state receives a financial tranche (French tranch - series, part; financial credit), but does not fully comply with the commitments that are made in this regard, including the conduction of reforms in the military sphere, protection of the rights of victims of violent crimes, the creation of a fair trial, etc.

However, as some researchers have aptly concluded in this regard, regarding the mental component, then to change attitude to the man, the task is complex, systemic and affects consciousness. Moreover, the consciousness is not an individual and not a separate community, but the whole society, its social and cultural layers.

Important, in the context of the problematic that is studied in this scientific article, there is another conclusion of scientists: the norm becomes legal only when it is reflected in the social practice (Kyrychenko, 2015).

Practical aspects and problems of realization in Ukraine of the international mechanism of protection of the rights of victims of the military conflict in the East of Ukraine.

The essence of the specified problematic is that our country, contrary to the requirements of the generally accepted international legal norms, according to which any state which, in one form or another, has made it binding on its territory, cannot explain by the lack of material, financial and other resources of the violation of fundamental human and civil rights and freedoms, as well as narrowing their scope and content.

Instead, Ukraine, based on the decision of the Constitutional Court of 25.01.2012 № 3-rp / 2012 (the official interpretation of the article 1 of the Constitution of Ukraine), chose a completely different approach, namely: when adopting new laws or amending current laws, it allows the narrowing of the content and scope of existing rights and freedoms, including those that are the subject in this research article (Constitutional court of Ukraine, 2012). 
As a result, our state is not fulfilling its obligations and improperly ensuring the rights of victims of the military conflict in Donbas starting from 2014 to the present.

In particular, until the adoption of the Law of Ukraine "On ensuring the rights and freedoms of internally displaced persons" in October 2014, the Government of Yatsenyuk blocked receiving pensions and other social benefits of those who remained living in the occupied territories of the East of our country, and later created other obstacles for this category of victims of military conflict at the regulatory level (Verkhovna Rada of Ukraine, 2014).

In addition, neither in the banking nor in the social spheres, Ukraine has not provided any benefits and preferences, which are provided not only by the norms of international law, but by the above-specified Law of Ukraine, for the specified victims of the war.

There are even more problems that are related to the availability of legal gaps and conflicts, as well as inconsistencies with the content of international legal acts of the practice of assigning pensions to servicemen and persons, who are equated to them who have become war invalids.

Instead of as provided in civilized countries (USA, FRG, England, etc.), for establishing a single number of benefits for all categories of people with disabilities, they are based on two main criteria in Ukraine - the presence of work experience before injury (mutilation, etc.), as well as the amount of salary that had been received before.

In addition, as a result, some war invalids receive several times higher pensions than others, which is a gross violation not only of international law but also of the art. 24 of the Constitution of Ukraine, according to which citizens have equal constitutional rights and freedoms and are equal before the law.

No less disgusting in this regard is another practice, when due to lack of funds in the State Budget of Ukraine, social payments (compensations, amounts of money that the court ordered to be paid, etc.) in the relevant state institutions are made according to the lists that are approved by him, not taking into account neither the level of inflation nor other financial and price aspects that prevailed at that time in the state, at the time of their receipt by creditors (direct victims).

And there are many such factors in the historical socially dangerous practice of our state that are directly and indirectly related to the protection of the rights of victims of hybrid warfare in the East, which can also be attributed to the peculiarities of the implementation of our state's international obligations on the specified problematic.

"The freshest" example in this regard is the misuse of funds that have been allocated to the Government of Ukraine to combat COVID-19, which were aimed at the road construction by the latter. 
All this testifies to the systemic character of the problems that have arisen in connection with the need to protect the rights of victims of the military conflict in Donbass, as well as to the need to resolve them as soon as possible in the context of the Euro-Atlantic intentions of Ukraine and the desire to join the EU and NATO as soon as possible.

\section{Conclusions}

Therefore, based on the results of the study, it can be argued that the rights of all categories of victims of the military conflict in the East of Ukraine are inadequately protected today in Ukraine, as it is provided by the international mechanism on these issues.

In this case, the main circumstances that negatively affect the specified activity, are not only and not so much disharmony (inconsistencies) of norms of domestic and international law, that are directly related to solving the problems of the specified persons, how much low is the level of fulfillment of Ukraine's obligations of international legal character, as well as a gross violation of the internationally recognized principle of the rule of law by our state, which is reflected in the art. 8 of the Constitution of Ukraine, and of other conceptually important principles of international law, which govern the spheres of protection of victims (injured) of military conflicts.

No less "vulnerable" to this process is the misuse of funds and other material resources that are allocated to solving tasks, which are involved in the problematic of research, both by the Government of Ukraine and by its other partners (French pretensive - participant of the game) (primarily, by the United States, Canada, the European Union, etc.) at improving the structure and combat capability of the Armed Forces of Ukraine, to protect the population living in the territories that are close to the military conflict, the so-called "gray areas" (neutral human settlements that are located between the parties to the military confrontations) of social rehabilitation of victims of hybrid war: fight against corruption directly in the combat units of military formations of our state; etc. (Bulko, 2010).

Thus, there is a complex applied problem, which has signs of relevance, theoretical and practical significance, which necessitated its need of analysis in this scientific article, and also created an appropriate methodological basis, including pros and cons, for further similar scientific research in this direction in order to create appropriate conditions for the realization of the international mechanism for the protection of the rights of victims of military conflict in the East of our country. 


\section{Bibliographic References}

BABIN, Borys. 2015. Legal standards of the Council of Europe in the field of effective investigations. Criminal-executive policy of Ukraine and the European Union: development and integration: coll. Materials of International scientific-practical conference. Kyiv, Ukraine.

BULKO, Oleksandr. 2010. Large dictionary of foreign words. 35 thousand words. Ed. 3rd, corrected, reworked. p. 704. Moscow, Russia.

CONSTITUTIONAL COURT OF UKRAINE. 2012. Decision of the Constitutional Court of Ukraine of 25.01.2012 № 3-rp / 2012 in the case of the constitutional petition of the Board of the Pension Fund of Ukraine on the official interpretation of article 1, parts one, two, three of article 95, part two of article 96, paragraphs 2, 3, 6 of Article 116, part two of article 124, part one of article 129 of the Constitution of Ukraine, paragraph 5 of part one of Article 4 of the Budget Code of Ukraine, paragraph 2 of part one of article 9 of the Code of administrative procedure of Ukraine in systematic connection with certain provisions of the Constitution of Ukraine (case № 1-11/2012). Available online. In: http://search.ligazakon.ua. $\square$ link1. Consultation date: 01/08/2020.

DANYLCHENKO, Yuriy. 2018. Terrorism: phenomenon, determination, counteraction". AutoAbstract of dissertation of doctor of legal sciences: 12.00.08. Kharkiv, Ukraine.

DECREE OF THE PRESIDENT OF UKRAINE. 2015. National strategy in the field of human rights: approved by the Decree of the President of Ukraine dated 25.08.2015 № 501/2015. Available online. In: http:// zaron.rada.gov.ua. Date of consultation: 01/08/2020.

GOLINA, Volodymyr; GOLOVKIN, Bohdan; VALUISKA, Maryna. 2014. Criminology. A textbook. Kharkiv, Ukraine.

GOLOVATYI, Serhiy. 2006. The rule of law: monograph: in 3 books. Kyiv. Available online. In: http://uk.m.wikipedia.org. Date of consultation: 01/08/2020.

KHAVRONIUK, Mykola. 2005. Modern pan-European criminal law: problems of harmonization. Monograph. Kyiv, Ukraine.

KYRYCHENKO, Volodymyr. 2015. Penitentiary system of Ukraine - reforms for the sake of reforms. Criminal and executive policy of Ukraine and the European Union: development and integration: coll. Materials of International scientific-practical conference. Kyiv, Ukraine. 
Alexander G. Kolb, Malvina Hrushko, Hanna Teteriatnyk, Olha Chepik-Trehubenko y Olha Kotliar 348 Peculiarities of Realization of the International Mechanism for the Protection of the Rights of Victims of Armed Conflict in the East of Ukraine

MALIAR, Ganna. 2016. Analysis of the prosecution of the legislature and judiciary to criminal responsibility for the preparation, casting and waging of an aggressive war. Available online. In: htts://ccl.org. uanewsanaliz-vit. Date of consultation: 01/08/2020.

MOKLIAK, Volodymyr. 2020. Countering terrorist activity in Ukraine. AutoAbstract of dissertation of candidate of legal sciences: 12.00.08. p. 19. Kharkiv, Ukraine.

PODILCHAK, Olha. 2015. Violation in Ukraine of Article 3 of the Convention for the Protection of Human Rights and Fundamental Freedoms. Criminal and executive policy of Ukraine and the European Union: development and integration. Kyiv, Ukraine.

STEPANCHENKO, Oleksiy. 2018. Countering ethno-religious terrorism: criminological, victimological and geopolitical analysis. AutoAbstract of dissertation of Doctor of Legal Sciences: 12.00.08. Kharkiv, Ukraine.

UN GENERAL ASSEMBLY. 1974. UN General Assembly Convention of 14 December 1974: Resolution 3314 (on the delimitation of the "aggression" concepts). Available online. In: htts://uk.m.wikipedia. org. Date of consultation: 04/08/2020.

VERKHOVNA RADA OF UKRAINE. 1949. Convention relative to the treatment of prisoners of war of 12 August 1949. Available online. In: http://zakon.rada.gov.ua/cqi-bin/laws/main.cqi. Consultation date: 02/08/2020.

VERKHOVNA RADA OF UKRAINE. 1951. Convention about the status of refugees of 28th of July 1951. Legislation of Ukraine. Available online. In: http://zakon.rada.gov.ua/cqi-bin/laws/main.cqi. Date of consultation: 01/08/2020.

VERKHOVNA RADA OF UKRAINE. 1977. Additional Protocol I to the Geneva Conference of 8 June 1977 on the Protection of victims of non-international armed conflicts. Legislation of Ukraine. Available online. In: http://zakon.rada.gov.ua/cqi-bin/laws/main.cqi. Date of consultation: 02/08/2020.

VERKHOVNA RADA OF UKRAINE. 1977. Additional Protocol II of 8 June 1977 to the Geneva Conference of 12 August 1949 on the Protection of victims of non-international armed conflicts. Legislation of Ukraine. Available online. In: http://zakon.rada.gov.ua/cqi-bin/laws/main.cqi. Date of consultation: 02/08/2020.

VERKHOVNA RADA OF UKRAINE. 1983. European Convention on the compensation of victims of violent crimes of 24 November 1983. 
Available online. In: http://zakon.rada.gov.ua/cqi-bin/laws/main.cqi. Date of consultation: 04/08/2020.

VERKHOVNA RADA OF UKRAINE. 1998. Rome Statute of the international criminal court of July 17, 1998. Available online. In: http://zakon.rada. gov.ua/cqi-bin/laws/main.cqi. Date of consultation: 04/08/2020.

VERKHOVNA RADA OF UKRAINE. 2004. On international agreements: Law of Ukraine of June 29, 2004, № 1906-IV. p. 540.

VERKHOVNA RADA OF UKRAINE. 2006. On the execution of decisions and application of the case law of the European Court of Human Rights: Law of Ukraine of 23.02.2006 № 3477-IV.p 260.

VERKHOVNA RADA OF UKRAINE. 2011. On refugees and persons, who need of additional temporary protection: Law of Ukraine of July 8, 2011, № 3671-VI. p. 146.

VERKHOVNA RADA OF UKRAINE. 2014. On ensuring the rights and freedoms of internally displaced persons. Law of Ukraine № 1706-VII. №1. p. 1.

VERKHOVNA RADA OF UKRAINE. 2015. On the statement of the Verkhovna Rada of Ukraine "On repelling the armed aggression of the Russian Federation" and overcoming its consequences: Resolution of the Verkhovna Rada of Ukraine of 21.04.2015 № 337-VIII. p. 153. 
Vol. 39 N $^{\circ} 71$

Esta revista fue editada en formato digital y publicada en diciembre de 2021, por el Fondo Editorial Serbiluz, Universidad del Zulia. Maracaibo-Venezuela 